\title{
SEBARAN SITUS PALEOLITIK DI TEPI ALIRAN SUNGAI WALENNAE WILAYAH BONE BARAT, SULAWESI SELATAN
}

\author{
Distribution of Palaeolithic Sites in the River of Walennae River \\ West Bone Region, South Sulawesi
}

\author{
Budianto Hakim \\ Balai Arkeologi Sulawesi Selatan \\ Jl. Pajjaiyang No. 13 Sudiang Raya Makassar, Indonesia \\ budiantohakim@yahoo.co.id; budianto.hakim@kemdikbud.go.id
}

Naskah diterima: 23/03/2018; direvisi: 08/05-25/11/2018; disetujui: 30/11/2018

Publikasi ejurnal: 21/12/2018

\begin{abstract}
Almost all the paleolithic sites in Cabbenge, Soppeng are on the banks of the Walennae River, both located on ancient river terraces as well as those that exist today. Considering the Walennae River is located in Bone District (Bontocani region), it is very possible in the Bone region connected to the Walennae River, there are paleolithic sites that contemporary with the oldest occupancy in Soppeng District. This has been guided by the results of the thesis study of Archaeology Departement of Hasanuddin University students, in 1990 of Mallinrung area, Libureng, Bone, which reported the first time that lhitic artifacts were found in the area, including those with the characteristics of paleolithic technology. In the framework of expanding the potential area of paleolithic archaeological remains on the banks of the Walennae River, this study focused on the Bone West region, including Bengo, Lamuru, Lappariaja, Kahu and Libureng Districts. Exploration surveys are intended to obtain information on the distribution of sites related to paleolithic potential in the region. The results of the study showed the development of the technology of the palaeolithic stone tools, including: flakes, hand-held axes, impact axes, and ax axes. Technological developments in stone tools and paleolithic culture in the Bone West region, as well as showing paleolithic cultural connectivity both in the Soppeng region and in the Old Walennae depressed regions, especially in the Bone West region.
\end{abstract}

Keyword: Human, Technology, Artifact, Culture, Walennae.

\begin{abstract}
Abstrak
Hampir semua situs paleolitik di Cabbenge, Soppeng berada di tepi Sungai Walennae, baik yang terletak di teras sungai purba maupun yang ada sekarang ini. Mengingat Sungai Walennae berhulu di Kabupaten Bone (wilayah Bontocani), maka sangat memungkinkan di wilayah Bone yang terkoneksi dengan Sungai Walennae, terdapat situs-situs paleolitik yang sejaman dengan masa hunian tertua di wialayah Kabupaten Soppeng. Hal ini telah dipandu oleh hasil penelitian skripsi mahasiswa arekeologi, Unhas tahun 1990 di wilayah Mallinrung, Libureng, Bone yang melaporkan pertama kali bahwa di daerah tersebut ditemukan artefak litik, termasuk yang memiliki ciri teknologi paleolitik. Dalam kerangka memperluas area potensi tinggalan arkeologi jaman paleolitik di tepi Sungai Walennae, penelitian ini difokuskan pada wilayah Bone Barat, meliputi Kecamatan Bengo, Lamuru, Lappariaja, Kahu dan Libureng. Survei eksploratif dimaksudkan untuk memperoleh informasi sebaran situs terkait potensi paleolitik di wilayah tersebut. Hasil penelitian menunjukkan perkembangan teknologi alat batu paeolitik, diantaranya: alat serpih, kapak genggam, kapak perimbas, dan kapak penetak. Perkembangan teknologi alat batu dan budaya paleolitik di wilayah Bone Barat, sekaligus menunjukkan konektivitas budaya paleolitik baik di wilayah Soppeng maupun wilayah-wilayah depresi Walennae Purba khususnya di wilayah Bone Barat.
\end{abstract}

Kata Kunci: Manusia, teknologi, artefak, budaya, walennae. 


\section{PENDAHULUAN}

Berbicara masalah prasejarah Sulawesi Selatan, maka situs-situs yang berada di tepi Sungai Walennae dianggap oleh para ahli sebagai situs tertua dan merupakan situs yang kaya tinggalan arkeologi dan tidak akan pernah habis untuk penelitian tentang manusia purba, budaya dan lingkungannya. Hal tersebut ditandai dengan penemuan alat-alat batu yang sangat sederhana serta didukung oleh penemuan fosil binatang purba yakni spesies stegodon dan gajah bersama dengan babi dan spesies babi yang telah punah (Celebochoerus Heekereni) (Bellwood, 2007).

Kehidupan purba di atas pertama kali terkuak dari penelitian yang dilakukan oleh van Heekeren tahun 1947 dengan menemukan fosil taring besar dari babi, yang oleh Hooijer (1948) diberi nama Celebochoerus Heekereni. Tahun 1950 dan tahun 1970 van Heekeren kembali berhasil mengungkap tabir kehidupan manusia purba di lembah Walennae, Soppeng dengan menemukan beberapa serpih dan batuan alam yang diyakini sebagai alat-alat kerja manusia purba di daerah Calio (Poesponegoro \& Notosusanto, 1984, p. 103). Khusus penemuan alat-alat serpih tersebut secara taksonomi diberi istilah "Cabbenge Flakes Industry". Secara umum penemuan alat batu Cabbenge telah disepakati oleh para ilmuan sebagai salah satu satuan budaya yang disebut "kebudayaan Cabbenge" (Duli \& Nur, 2016; Heekeren, 1972, p. 67).

Artefak batu (litik) dalam studi arkeologi sebagai bukti kebudayaan tertua di muka bumi ketika manusia mulai hadir dan mengenal teknologi. Kebutuhan hidup yang mendorong mereka harus memanfaatkan benda-benda alam yang mudah ditemukan seperti batu sebagai peralatan. Perlahan, mereka kemudian membuat peralatan dengan cara memodifikasinya sehigga lebih efektif dan efisien ketika digunakan.

Perkembangan teknologi litik menunjukkan fase budaya yang sangat panjang dalam kehidupan manusia prasejarah. Pada awalnya, teknologi litik sangat sederhana dengan cara memanfaatkan batu kerakal dimodifikasi dengan cara dipangkas hanya beberapa kali. Namun seiring perkembangan kebutuhan yang semakin kompleks teknik modifikasi kemudian mulai berubah dengan teknologi yang lebih rumit untuk kebutuhan alat yang lebih efektif.

Teknologi litik tertua hingga saat ini dikenal dengan nama Budaya Oldowan. Teknologi litik yang ditemukan oleh Luis dan Mary Leakey pada lapisan paling tua di Olduvai Gorge, Afrika Selatan diperkirakan dikenal pada masa antara 2.6 hingga 1.7 juta tahun yang lalu (Pope, 1984, pp. 253-260).

Kawasan Prasejarah Cabbenge dalam studi arkeologi adalah bukti bahwa kawasan ini adalah daerah dengan kebudayaan tertua di Sulawesi. Pemanfaatan batu-batu kerakal sebagai peralatan hidup dengan teknologi yang masih sederhana memperlihatkan indikasi kehadiran awal manusia ketika pulau sulawesi mulai berpenghuni. Penelitian akhir tahun 2015 yang dilakukan oleh tim Australia yang bekerjasama dengan peneliti Indonesia menunjukkan bahwa Kawasan Cabbenge diperkirakan dihuni pada masa antara 118 hingga 194 ribu tahun yang lalu (Bergh et al., 2015). Namun bukti berupa fosil manusia belum ditemukan hingga saat ini.

Bukti-bukti artifisial berupa alat-alat batu dengan teknologi yang sangat sederhana merupakan alasan mendasar dalam memposisikan Sulawesi sebagai salah satu dari sedikit daerah di Indonesia yang telah dihuni pada masa plestosen, khususnya jaman batu tua (Paleolitik). Penelitian arkeologi di Lembah Walennae dengan panduan data-data paleoantropologi maupun geologi dianggap belum berhasil menemukan spesimen fosil manusia. Penelitian-penelitian terakhir pada situssitus yang ada di wilayah Bone dan Maros dengan temuan berupa gigi manusia juga belum berhasil memastikan kronologinya. 
Indikasi yang ada hanya menunjukkan bahwa temuan rangka manusia berasal dari periode yang lebih muda yaitu masa bercocok tanam atau periode neolitik (Fakhri, 2017; Hakim, 2017). Di sisi lain, melimpahnya temuan artefak batu memberi rangsangan pada upaya pencarian ataupun perluasan wilayah penelitian dalam melengkapi rekonstruksi sejarah kebudayaan Sulawesi Selatan, khususnya di wilayah Bone.

Hampir semua situs paleolitik di Cabbenge, Soppeng berada di tepi Sungai Walennae, baik yang terletak di tepi teras sungai purba maupun yang ada sekarang ini. Mengingat Sungai Walennae berhulu di Kabupaten Bone (wilayah Bontocani), maka sangat memungkinkan di wilayah Bone yang terkoneksi dengan Sungai Walennae terdapat situs-situs paleolitik yang sejaman dengan masa hunian tertua di Kabupaten Soppeng. Hal ini telah dipandu oleh hasil penelitian skripsi mahasiswa arkeologi, Unhas tahun 1989-1990 di wilayah Mallinrung, Libureng, Bone yang melaporkan pertama kali bahwa di daerah tersebut ditemukan artefak litik, termasuk yang memiliki ciri teknologi paleolitik (Hakim, 1990). Dalam konteks perluasan area survey untuk mengetahui lebih lanjut potensi arkeologi khususnya periode paleolitik di wilayah Bone Barat, dilakukan survey intensif terhadap daerah-daerah yang dulunya merupakan bagian dari teras purba sungai Walennae. Survey intensif ini difokuskan pada wilayah yang diduga memiliki tinggalan dari jaman paleolitik adalah wilayah Bone Barat, meliputi Kecamatan Bengo, Lamuru, Lappariaja, Kahu dan Libureng.

Dalam konteks mengisi ruang pemahaman tentang budaya paleolitik di tepi aliran sungai Walennae khususnya di wilayah Bone Barat, penelitian ini dimaksudkan untuk mengidentifikasi dan menginventarisasi situs-situs paleolitik di wilayah tersebut. Pengamatan terhadap artefak budaya pada situs-situs paleolitik di wilayah ini menjadi bahan informasi untuk menjelaskan perkembangan teknologi alat batu dan perkembangan budaya paleolitik di sepanjang aliran sungai Walennae. Pada akhirnya, diperoleh gambaran tentang konektivitas antara situs-situs periode paleolitik baik di wilayah Soppeng maupun di wilayah-wilayah depresi Walennae Purba lainnya dengan situs-situs di wilayah Bone Barat sebagai satu kesatuan budaya dalam konteks daerah aliran sungai Walennae.

\section{METODE PENELITIAN}

Berdasarkan

permasalahan sebagaimana diuraikan pada bagian sebelumnya, maka strategi penelitian menerapkan model kajian makro. Penelitian diorientasikan dalam usaha menemukan sejumlah lokus situs dengan menggunakan Geographical Position System (GPS), dan membuat kategorisasi artefak yang memiliki karakter budaya pada setiap situs yang diteliti. Tahapan awal dalam penerapan model kajian makro adalah melakukan plotting atau menempatkan lokasi situs pada suatu peta yang kemudian menjadi bahan analisa untuk melihat konteks sebaran situs (Gambar 1). Hal ini dimaksudkan untuk menjelaskan konektivitas situs-situs paleolitik di sepanjang aliran sungai Walennae. Selanjutnya, temuan-temuan baik artefak maupun non-artefak nantinya akan diperbandingkan guna meletakkan dalam kerangka peta budaya prasejarah. Selain itu, observasi juga dilakukan terhadap lingkungan situs untuk menggambarkan pola pemukiman dan melihat kemungkinan adanya hubungan antara situs dalam satu kawasan berdasarkan kategorisasi artefaknya. Model kerja ini dipilih berdasarkan asumsi bahwa totalitas lingkungan yang ada di kawasan Bone barat merupakan satu-kesatuan dalam memberi dukungan terhadap berlangsungnya suatu kebudayaan pada masa tertentu.

Tahapan penelitian ini, bersifat pengumpulan data dengan menggunakan metode survei, yaitu melakukan 
pengamatan, pengidentifikasian temuan dan lingkungan situsnya, melihat potensi artefak. Data-data hasil penelitian nantinya akan digunakan dalam rangka membangun hipotesis untuk menggambarkan perkembangan teknologi alat batu dan budaya paleolitik di kawasan Bone barat.

\section{HASIL DAN PEMBAHASAN \\ 1. Deskripsi Situs}

\section{a. Situs Lita atau Wanuae}

Secara administrasi situs Lita termasuk wilayah Dusun Wanuae, Desa Poleonro, Kecamatan Lamuru, Kabupaten

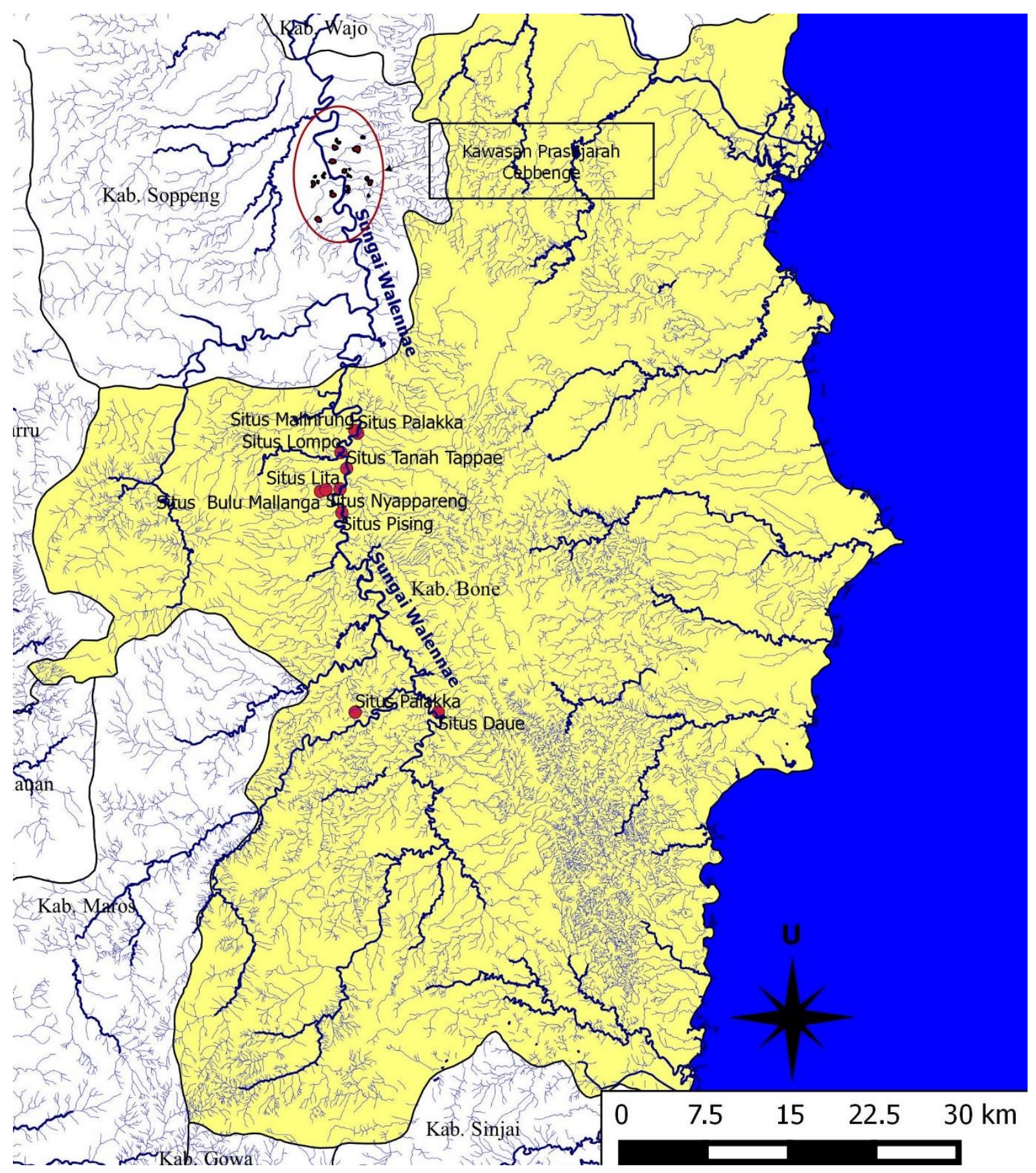

Gambar 1. Peta Sebaran Situs-situs di tepi aliran Sungai Walennae, Bone Barat

(Sumber: Dokumentasi Balar Sulsel, Tahun 2017) 


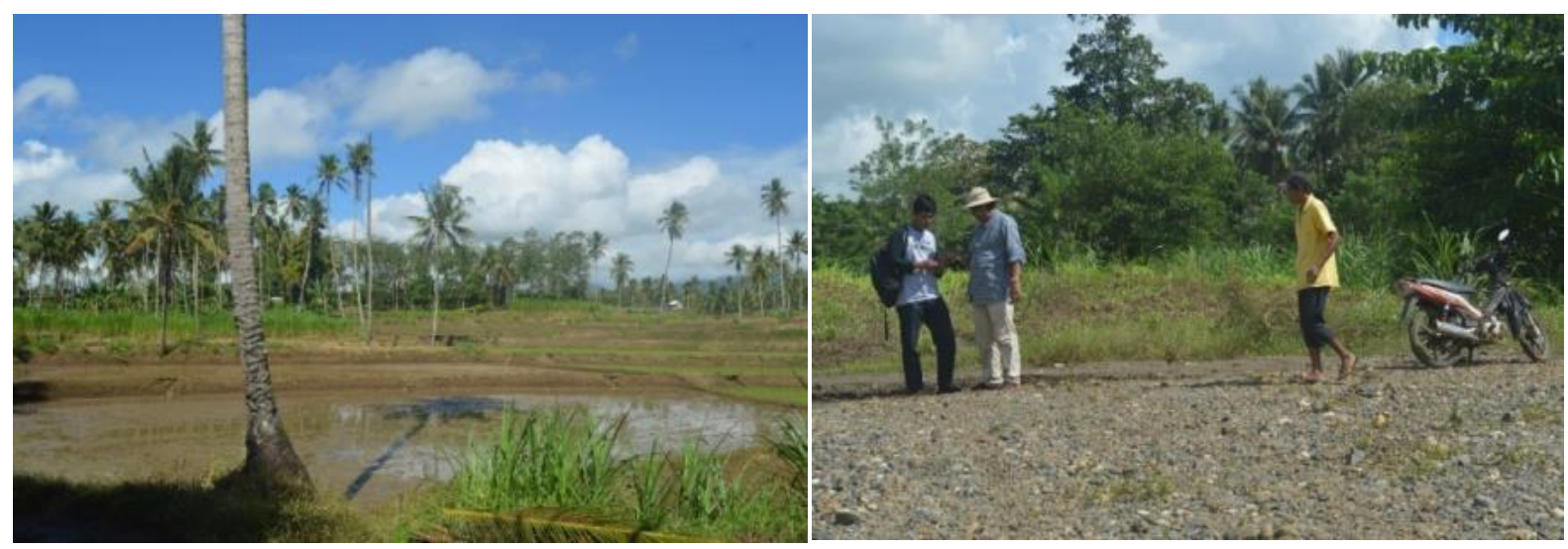

Gambar 2. Teras sungai purba dan jalan pengerasan menuju Sungai Walennae yang banyak mengandung alat litik

(Sumber: Dokumentasi Balar Sulsel, Tahun 2017)

Bone. Keletakannya secara astronomi, yaitu 04³7'04.5" (Selatan) dan 11959'47.6" (Timur) atau berada $\pm 2 \mathrm{Km}$ dari tepian jalan aspal poros Lamuru-Soppeng. Untuk mencapai situs ini dihubungkan oleh jalan pengerasan dari tepi jalan aspal hingga tepi sungai Walennae. Sepanjang jalan melewati perkebunan dan persawahan yang berterasteras. Dulunya sekitar persawahan adalah bekas pemukiman lama sebelum berpindah ke tepi jalan aspal sekarang ini. Berdasarkan info masyarakat bahwa dulunya di tepi sungai tersebut terdapat tambang batu dan pasir yang dikelola oleh masyarakat setempat (Gambar 2).

Jika melihat lansekap situs ini yang melandai dan miring ke arah sungai, diperkirakan dulunya adalah bagian dari teras sungai purba. Sekarang ini sebagian besar lahan situs dimanfaatkan oleh penduduk setempat sebagai lahan pertanian (sawah dan kebun). Pada teras tersebut banyak singkapan batu sungai pada beberapa titik (khususnya pada pematang sawah atau bagian tanah yang tergali). Di antara singkapan batuan sungai tersebut juga ditemukan alat litik. Selain pada teras, alat litik juga banyak ditemukan pada tepi sungai maupun batauan yang dijadikan pengerasan jalan.

\section{b. Situs Pising}

Terletak dalam wilayah Desa Mattampa Walie, Kecamatan Lamuru,
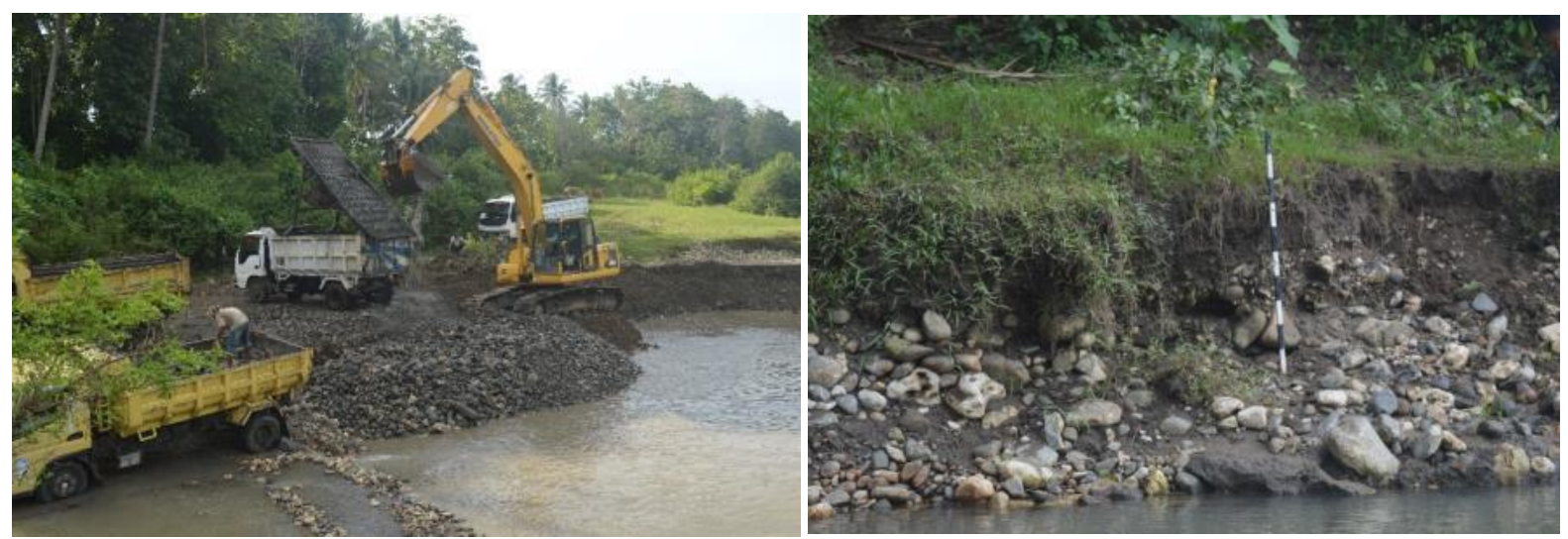

Gambar 3. Penambangan batu dan singkapan batuan di tebing anak sungai yang bermuara di Sungai Walennae

(Sumber: Dokumentasi Balar Sulsel, Tahun 2017) 


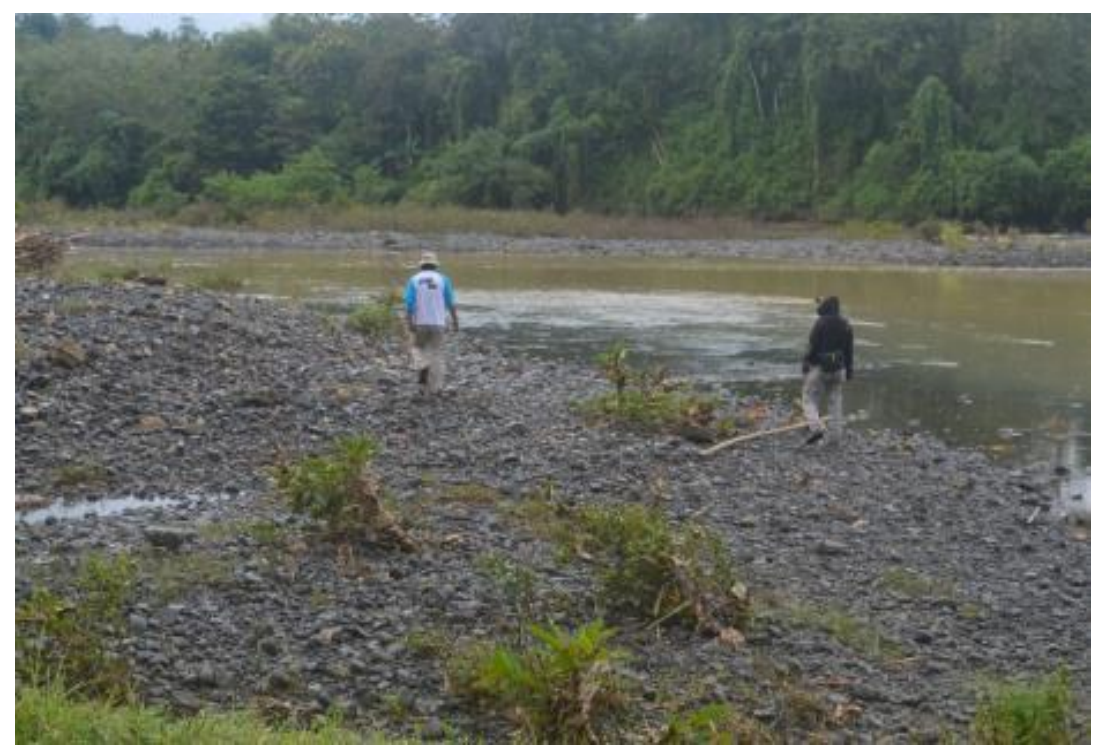

Gambar 4. Kolekting artefak litik di tepi sungai

(Sumber: Dokumentasi Balar Sulsel, Tahun 2017)

Kabupaten Bone. Secara astronomi situs ini berada pada posisi $04^{\circ} 38^{\prime} 13.2^{\prime}$ ' (Selatan) dan 11959'52.7” (Timur). Untuk mencapai situs ini dapat ditempuh dengan roda empat atau dua melewati jalan pengerasan dari tepi jalan aspal poros Lamuru-Soppeng hingga tepi Sungai Walennae yang berjarak kurang lebih $2 \mathrm{Km}$. Hingga sekarang, di tepi sungai tersebut masih berlangsung penambangan pasir maupun batuan yang dikelola oleh masyarakat setempat.

Batuan pengerasan jalan sebagian adalah alat litik, baik yang berukuran kecil maupun besar. Alat batu juga banyak ditemukan di tepi Sungai Walennae. Hamparan batuan sungai tersebut sebagian telah mengalami pengerukan oleh mobil ekskavator, sehingga pada beberapa titik banyak tumpukan batuan sungai yang tidak beraturan, demikian pula singkapan batuan di tebing-tebing sungai (Gambar 3). Selain alat litik, ditemukan pula beberapa fosil-fosil kerang maupun fosil kayu.

\section{c. Situs Lompo}

Berada disisi utara Sungai Walennae yang masih satu aliran dari situs Lita dan Pising. Secara administrasi situs ini berada dalam wilayah Desa Senggeng Palie, Kecamatan Lamuru, Kabupaten Bone atau secara astronomi berada pada posisi 0435'19.4" (Selatan) dan 11959'50.3” (Timur). Untuk mencapai situs, yaitu menyusuri jalan pengerasan samping kantor Polisi Sektor Lamuru hingga di pinggir Sungai Walennae berjarak kurang lebih 3 $\mathrm{Km}$.

Menurut keterangan penduduk setempat bahwa penambangan pasir dan batu pernah berlangsung di lokasi ini. Alat litik banyak ditemukan pada halaman rumah penduduk maupun sepanjang jalan pengerasan. Selain itu, alat batu lebih banyak ditemukan pada pinggiran sungai di antara hamparan batuan sungai. Keseluruhan batuan untuk pengerasan jalan sepanjang jalan poros Lamuru-Soppeng hingga pinggir sungai adalah dari Sungai Walennae yang ada di situs ini.

\section{d. Situs Bulu Mallanga}

Situs ini berada pada sebuah bukit yang banyak singkapan batuan gamping dan sebagian besar lahan situs telah difungsikan sebagai perkebunan coklat. Secara administrasi situs ini berada pada wilayah dusun Wanuae, Desa Poleonro, Kecamatan Lamuru, Kabupaten Bone serta secara astronomi menempati posisi 04³7'11.6" (Selatan) dan 11958'50.9” (Timur). Untuk 


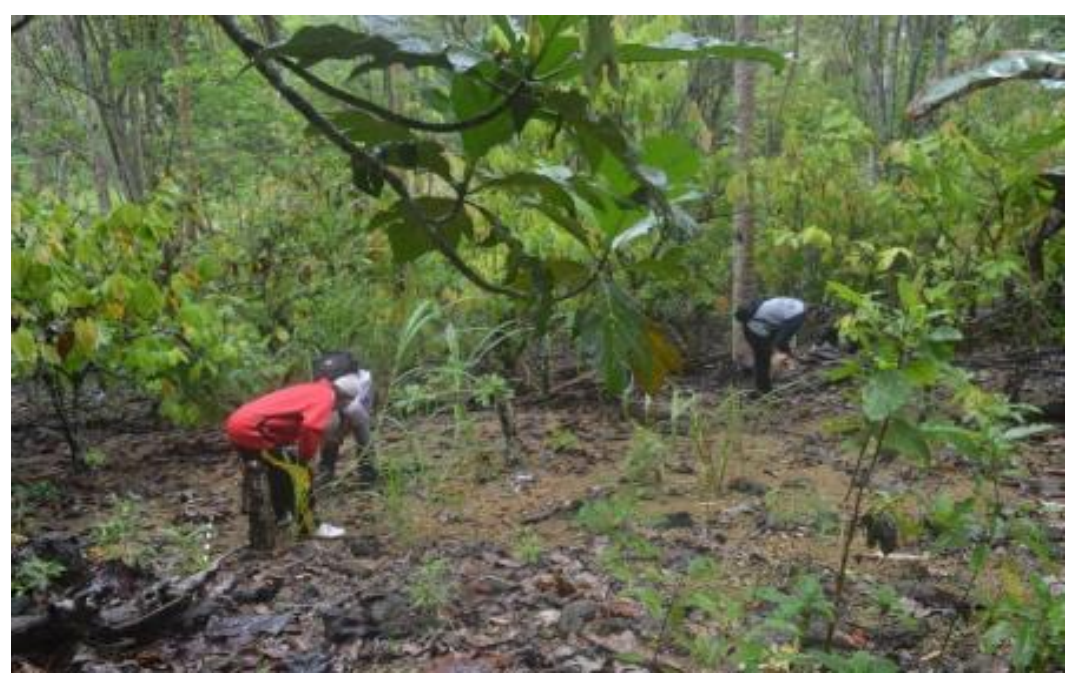

Gambar 5. Kolekting temuan litik di Situs Bulu Mallanga

(Sumber: Dokumentasi Balar Sulsel, Tahun 2017)

mencapai situs, yaitu menyusuri jalan aspal desa di antara pemukiman penduduk hingga lapangan sepak bola Desa Poleonro. Situs ini menempati areal seluas kurang lebih 500 meter persegi yang sisi utara dan barat bersinggungan dengan lapangan sepak bola dan perkampungan.

Di antara singkapan batu gamping disela-sela pohon coklat ditemukan beberapa artefak litik jenis serpih berbahan gamping, berukuran kecil serta memiliki faset penyerpihan yang terlihat masih segar. Tampaknya alat litik di situs ini keberadaannya adalah insitu dan mungkin dibuat pada masa kemudian (Mesolitik). Sementara alat litik yang ditemukan pada jalan pengerasan jalan desa dekat lapangan sepak bola memiliki ciri teknologi alat batu tua, yaitu memiliki patina yang sangat tebal. Jika berdasarkan ciri dan penampakan lansekap yang ada sekarang bahwa situs ini yang bersinggungan dengan pemukiman penduduk dulunya merupakan teras sungai purba. Sehingga pada jalan pengerasan dan pada beberapa singkapan batuan sungai ditemukan beberapa artefak batu Paleolitik yang dicirikan dengan ukuran dan tingkat patinasi yang tebal. Keletakan situs ini dari posisi aliran Sungai Walennae $\pm 3 \mathrm{~km}$.

\section{e. Situs Palakka}

Termasuk dalam wilayah dusun Palakka, Desa Sengeng Palie, Kecamatan Lamuru, Kabupaten Bone dan secara

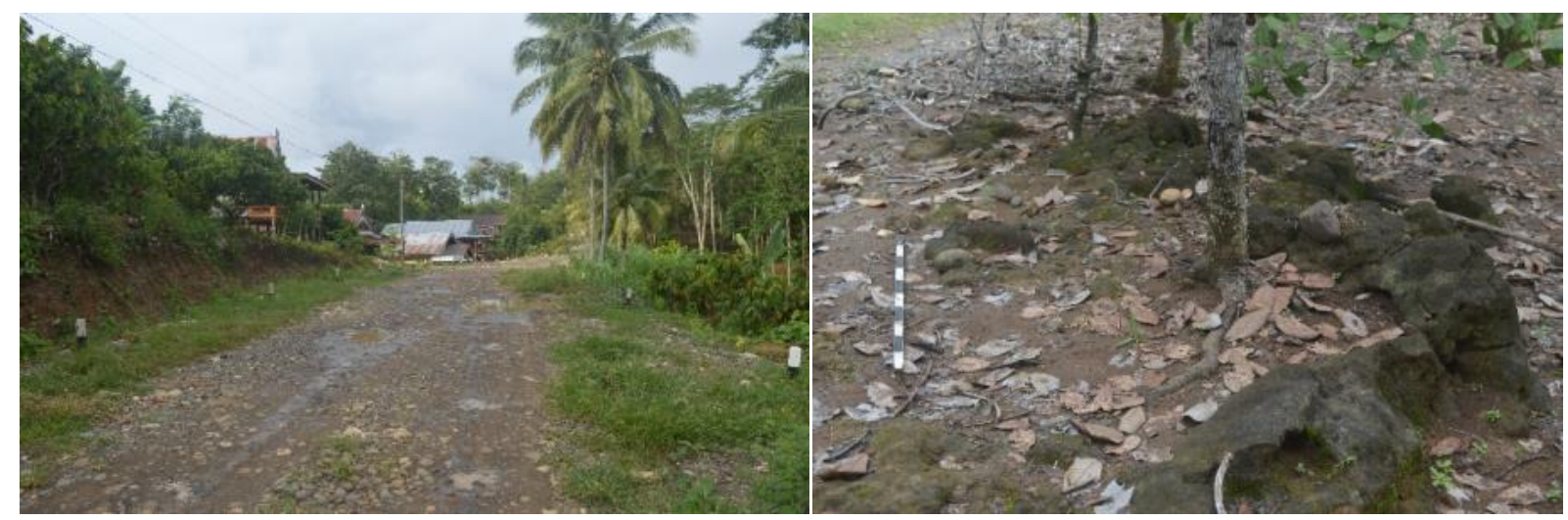

Gambar 6. Sinngkapan batuan pasir (sand stone)

(Sumber: Dokumentasi Balar Sulsel, Tahun 2017) 

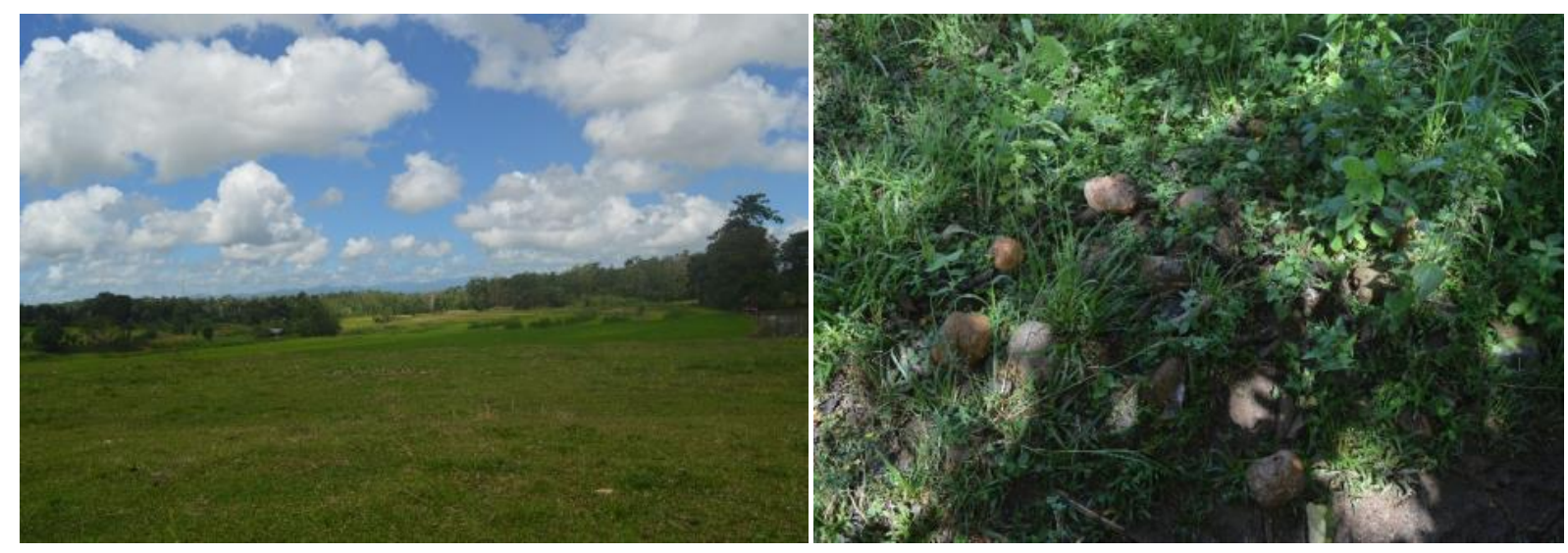

Gambar 7. Dataran yang lapang merupakan teras sungai purba dikelilingi sawah dan kebun, serta sebaran batuan dan litik

(Sumber: Dokumentasi Balar Sulsel, Tahun 2017)

astronomi berada posisi 04'34'23.5" (Selatan) dan $120^{\circ} 00^{\prime} 38.3^{\prime \prime}$ (Timur). Situs ini berada ditepi sungai Walennae berjarak \pm $5 \mathrm{Km}$ dari poros jalan aspal LamuruSoppeng. Untuk sampai di tepi sungai kita menyusuri jalan desa berupa jalan pengerasan. Menurut keterangan penduduk bahwa batu maupun pasir yang dipakai untuk pengerasan jalan, termasuk batuan yang terdapat di sekitar rumah masyarakat sepanjang jalan berasal dari sungai Walennae.

Perkampungan, sawah dan kebun dari tepi jalan aspal poros Lamuru-Soppeng hingga 500 meter dari tepi sungai sekarang merupakan teras Sungai Walennae purba. Sepanjang jalan pengerasan dan halaman rumah masyarakat inilah banyak ditemukan artefak litik paleolitik. Selain itu, artefak litik juga banyak ditemukan di antara hamparan batuan sungai di tepi Sungai Walennae. Sepanjang jalan di halaman rumah penduduk dijumpai beberapa singkapan bongkahan batuan pasir yang berukuran besar (Gambar 6). Batuan pasir tersebut memiliki persamaan dengan batuan pasir di sekitar Cabbenge yang banyak mengikat temuan fosil vertebrata, seperti gajah, kura-kura raksasa, babi purba, dll.

\section{f. Situs Daue}

Secara administrasi berada dalam wilayah dusun Daue, Desa Mattiro Bulu,
Kecamatan Libureng, Kabupaten Bone dan secara astronomi terletak pada posisi 0447'50.0" (Selatan) dan 120 04'31.3”' (Timur). Situs ini merupakan hamparan tanah datar yang dijadikan lahan persawahan maupun perkebunan dan terletak $\pm 1 \mathrm{Km}$ dari jalan aspal poros Libureng-Sinjai atau berada 300 meter di sebelah utara Sungai Walanae yang berhulu di sekitar gunung kapur Bontocani.

Situs ini merupakan teras purba yang pernah dihuni oleh manusia purba dengan indikator permukaan tanah ke arah sungai sedikit miring serta banyak ditemukan kerakal batuan gamping dan chert yang berukuran besar ataupun kecil serta banyak ditemukan artefak litik yang berciri paleolitik. Tampaknya batuan dan alat litik di situs ini tersingkap secara insitu.

Selain alat-alat litik yang memiliki ciri dari masa Paleolitik yang ditemukan di situs ini, pada salah satu kebun berjarak \pm 50 meter dari tempat konsentrasi temuan alat litik paleolitik juga ditemukan alat batu yang berukuran kecil dan memiliki ciri faset yang masih segar (mungkin alat batu dari masa mesolitik atau akhir masa plestosen) (Gambar 7). Jika demikian, bahwa situs ini telah dhuni oleh manusia purba secara berkesinambungan. 


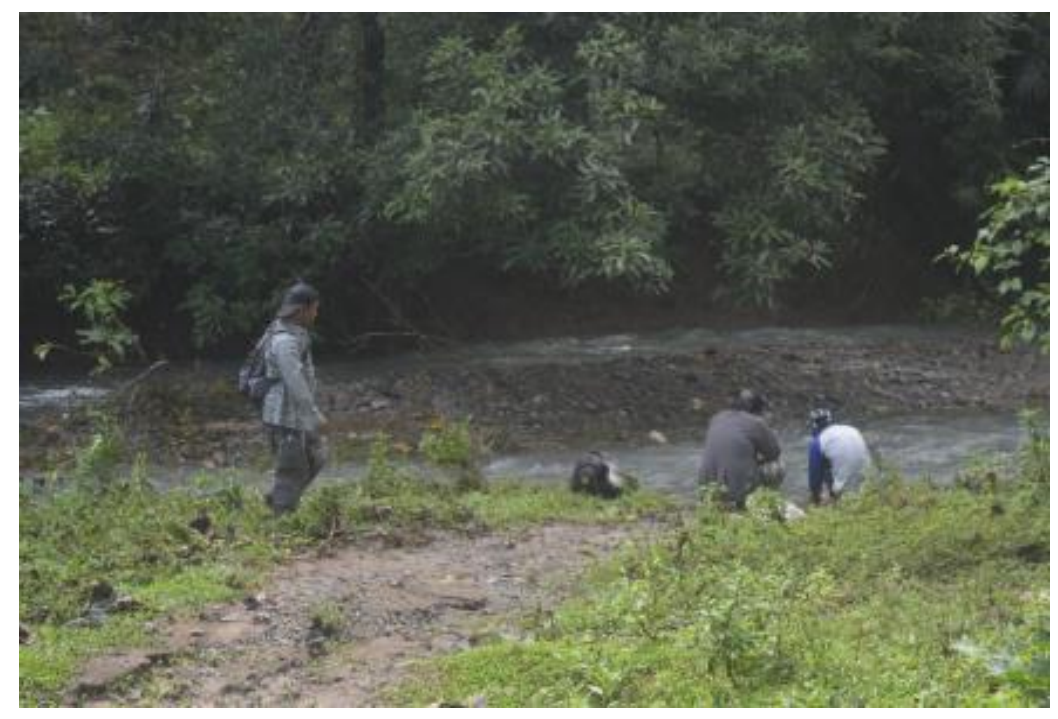

Gambar 8. Kolekting artefak di Sungai Mallinrung

(Sumber: Dokumentasi Balar Sulsel, Tahun 2017)

\section{g. Situs Mallinrung}

Berada dalam wilayah administrasi

Desa Mallinrung, Kecamatan Libureng, Kabupaten Bone dan secara astronomi terletak pada posisi $04^{\circ} 34^{\prime} 15.2^{\prime \prime}$ (Selatan) dan $120^{\circ} 00^{\prime} 30.0^{\prime \prime}$ (Timur). Situs ini berada di tepi jalan poros Libureng-Sinjai atau berada \pm 50 meter dari sisi Sungai Mallinrung (anak sungai Walennae).

Areal situs sebagian besar adalah pemukiman dan perkebunan. Oleh sebab itu, artefak litik banyak ditemukan di sekitar halaman rumah penduduk maupun kebun masyarakat yang ditanami coklat dan tanaman lainnya. Selain di halaman rumah dan kebun, di sepanjang jalan pengerasan menuju sungai juga banyak tersingkap artefak litik.
Umumnya artefak litik yang ditemukan di situs ini adalah jenis serpih dan sedikit alat inti yang berukuran besar. Alat litik yang berhasil dikumpulkan sebagian besar memperlihatkan faset-faset penyerpihan yang masih segar dan sebagian alat litik memperlihatkan faset-faset penyerpihan yang sudah tumpul dan membundar serta memiliki patina atau kerak batu yang tebal. Kemungkinan, situs ini diperkiran dihuni secara berkesinambungan hingga akhir masa prasejarah.

\section{h. Situs Nyappareng}

Merupakan wilayah dusun Nyappareng, Desa Selli, Kecamatan Bengo, Kabupaten Bone dan secara astronomi

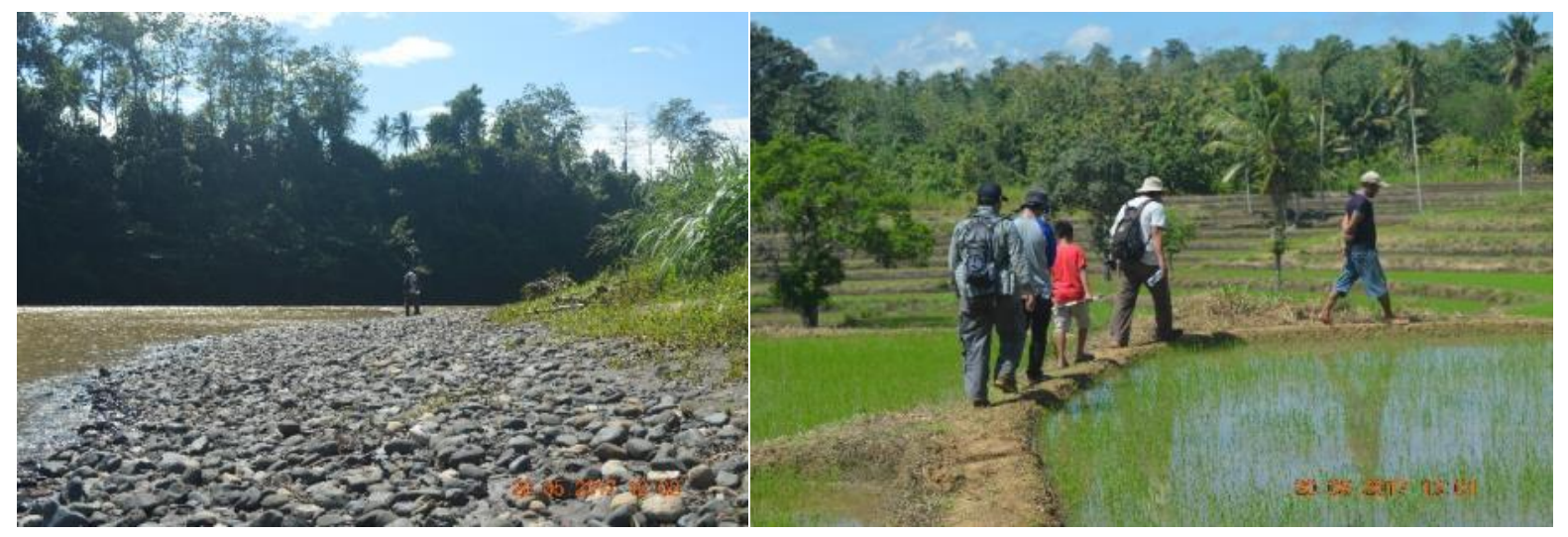

Gambar 9. Hamparan batuan ditepi Sungai Walennae dan lanskap teras sungai purba

(Sumber: Dokumentasi Balar Sulsel, Tahun 2017) 


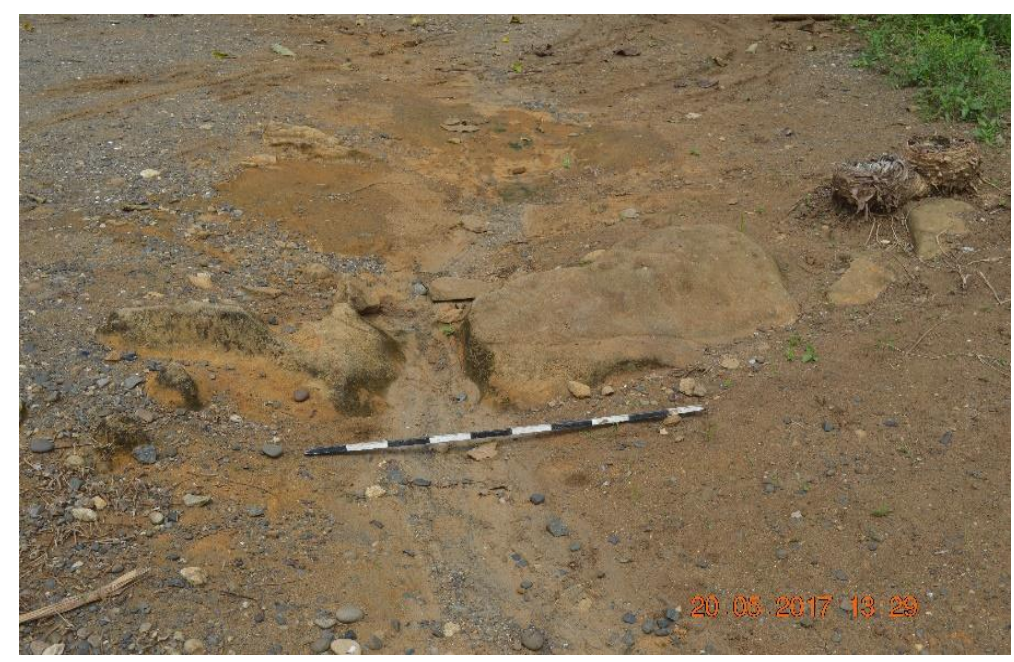

Gambar 10. Singkapan batuan pasir di halaman rumah penduduk (Sumber: Dokumentasi Balar Sulsel, Tahun 2017)

menempati posisi $04^{\circ} 37.694^{\prime}$ (Selatan) dan $119^{\circ} 59.717^{\prime}$ (Timur). Untuk mencapai situs dapat ditempuh dengan kendaraan roda dua maupun empat menyusuri jalan pengerasan dari tepi jalan aspal poros Bone-Makassar hingga mencapai pinggir Sungai Walennae yang berjarak $\pm 5 \mathrm{Km}$.

Situs ini adalah bekas teras purba yang sekarang menjadi perkampungan dan lahan pertanian. Alat litik yang berciri paleolitik umumnya ditemukan disepanjang jalan pengerasan jalan, halaman rumah penduduk, kebun serta terkonsentarasi di tepi sungai yang bercampur hamparan batu sungai. Di tepi sungai inilah juga sering masyarakat menambang pasir dan batu, termasuk batu pengerasan jalan diambil dari Sungai Walennae sekitar situs.

Jika berdasarkan ciri teknologi artefak litik yang berhasil dikumpulkan, tampaknya situs ini telah dimukimi secara berkesinambungan mulai dari masa paleolitik hingga akhir masa prasejarah. Hal ini ditandai oleh temuan artefak litik yang berfaset segar dan litik yang memiliki

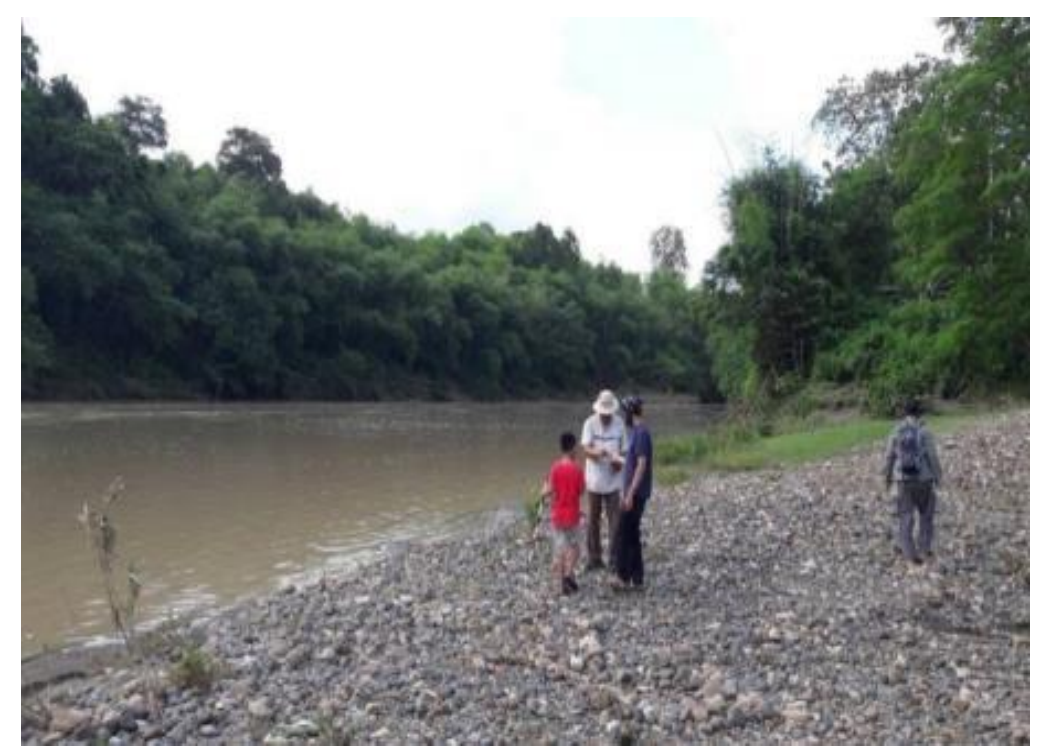

Gambar 11. Kolekting artefak hamparan batuan di tepi sungai

(Sumber: Dokumentasi Balar Sulsel, Tahun 2017) 
patinasi serta faset serpihan yang sudah membundar.

Meski belum ditemukan fosil hewan vertebrata di area situs ini, namun kondisi lingkungan atau lansekap situs memperlihatkan singkapan bongkahan batuan pasir. Ciri lansekap seperti ini adalah media pengikat fosil-fosil hewan purba sebagaimana ditemui di Lembah Sungai Walennae di daerah Soppeng. Tim penelitian hanya menemukan beberapa fosil kerang dan kayu.

\section{i. Situs Tanah Tappae}

Secara administrasi berada dalam wilayah dusun Tanah Tappae, Desa Bulu Allapporeng, Kecamatan Bengo, Kabupaten Bone dan secara astronomi berada pada posisi $04^{\circ} 36.580^{\prime}$ (Selatan) dan $120^{\circ} 00.668^{\prime}$ (Timur). Untuk sampai disitus ini, yaitu dari jalan aspal poros Bone-Makassar menyesuri jalan pengerasan menuju Dusun Tanah Tappae sejauh $1.5 \mathrm{~km}$. Situs ini juga sangat dekat dengan tepian Sungai Walennae, yaitu sekitar 500 meter.

Batuan yang terdapat di halaman rumah, kebun dan batu pengerasan jalan menurut keterangan penduduk berasal dari Sungai Walennae. Sementara artefak litik yang ditemukan juga umumnya terkonsentrasi di tepian sungai dan sebagian dari pengerasan jalan maupun yang terdapat di halaman rumah penduduk. Khusus di tepi sungai sangat banyak ditemukan artefak litik, demikian juga bahannya (Gambar 11).

\section{Teknologi Alat Batu Paleolitik di Kawasan Bone Barat}

Pada mulanya teknologi muncul dari upaya manusia untuk memenuhi kebutuhan hidupnya, termasuk untuk mempertahankan dirinya dari berbagai ancaman. Manusia dalam pengembaraan mencari kebutuhan hidupnya sering berhadapan dengan berbagai jenis bahan makanan, seperti binatang darat, ikan di air atau buah-buahan di pohon. Dalam memenuhi kebutuhan hidupnya, muncul naluri untuk memperoleh sumber makanan. Namun, keterbatasan kemampuan mendorong manusia untuk menggunakan alat bantu. Pada tahap paling awal, alat yang digunakan masih bersifat kebetulan dan instan, yaitu benda alam (batu, kayu dll) yang tersedia di sekitarnya.

Berbicara tentang peralatan manusia purba perhatian kita selalu tertuju pada alatalat batu. Hal ini tidak mengherankan karena artefak atau peralatan yang sampai kepada kita umumnya terbuat dari batu. Batuan sebagai bahan non-organik yang keras dapat bertahan melampaui berbagai zaman. Eksklusivitas tinggalan artefak litik telah menjadikan kehidupan manusia purba sering diidentikkan dengan Zaman Batu (Zaim, Tanudirjo, Widianto, \& Prasetyo, 2012)

Perkembangan teknologi litik atau teknologi batu meliputi sejarah yang sangat panjang, sepanjang zaman prasejarah itu sendiri. Teknik pembuatan alat litik tertua masih sangat sederhana, yaitu dengan cara membenturkan sebuah batu pada batu lainnya (block-on-block technique) hingga menghasilkan berbagai macam pecahan. $\mathrm{Si}$ pemecah kemudian memilah-milah pecahan yang memiliki sisi yang tajam untuk digunakan sebagai alat.

Sejalan dengan perkembangan pengetahuan manusia purba, teknik bentur tadi kemudian berkembang pada tingkat yang lebih kompleks yang dikenal sebagai teknik pemangkasan langsung (direct percussion). Suatu alat dihasilkan dengan menggunakan alat pemangkas (percutor) yang dibenturkan pada bahan yang dikerjakan dalam upaya membentuk alat yang diinginkan atau melapaskan serpihan yang akan dijadikan alat.

Teknik yang lebih maju lagi dalam teknologi alat batu adalah teknik pangkasan tidak langsung (indirect percussion), yaitu dengan cara menggunakan alat perantara seperti pahat yang dipukulkan dengan percutor pada bahan yang dikerjakan. Teknik semacam ini lebih dapat mengontrol arah pangkasan sehingga cenderung menghasilkan bentuk alat alat yang lebih 
sempurna. Teknik lainnya adalah teknik tekan (pressure technique), yaitu alat dihasilkan tidak lewat pangkasan tapi lewat tekanan saja. Dalam tekanan dengan perantara alat (pahat, dan tanduk) yang ditekankan pada bahan yang akan dikerjakan dengan kekuatan tangan atau tekanan berat badan hingga menghasilkan alat yang diinginkan (Zaim et al., 2012, pp. 102-103)

Untuk mengetahui teknologi alat batu yang berkembang di wilayah Kabupaten Bone, maka satu persatu alat-alat batu yang ditemukan di setiap situs akan dipilah-pilah dan selanjutnya akan dianalisis. Adapun jenis alat batu yang ditemukan dalam survei, adalah sebagai berikut :

\section{a. Alat Serpih (Flake Tools)}

Alat serpih yang dimaksud dalam penyajian ini, selain alat serpih yang memperlihatkan faset penyerpihan sudah mengalami pembundaran atau memiliki patina yang menebal, juga ada alat serpih yang masih menyisahkan faset serpihan yang meruncing atau masih segar. Kedua jenis alat serpih tersebut hampir ditemukan di setiap situs yang telah disurvei di wilayah Kabupaten Bone bagian barat. Mengingat penelitian kali ini adalah survei, maka sangat susah diketahui keletakan alat batu secara kontekstual, sebab seluruh alat batu yang dikumpulkan adalah kondisinya bercampur secara bersama-sama pada permukaan tanah situs.

Alat serpih secara teknologi umumnya adalah alat batu yang dibuat dari serpihan batu yang sengaja dipangkas dari intinya. Namun ada juga alat serpih yang memang berasal bukan dari serpihan batu, akan tetapi batu inti yang dipangkas oleh pembuatnya hingga menemukan bentuk yang tipis dan tajam. Dengan demikian, ada alat serpih yang dibuat berdasarkan ide yang disiapkan dalam benak (mental template) dari si pembuat, baik bentuk maupun fungsinya. Namun ada juga, alat serpih yang hanya dibuat seadanya saja, sebab bentuknya sudah ada dan hanya menambah tajaman pada sisi tertentu sesuai yang diinginkan dari pembuatnya.

Temuan alat serpih yang berpatina dan segar yang ditemukan pada semua situs. Untuk yang berpatina seluruhnya berjumlah
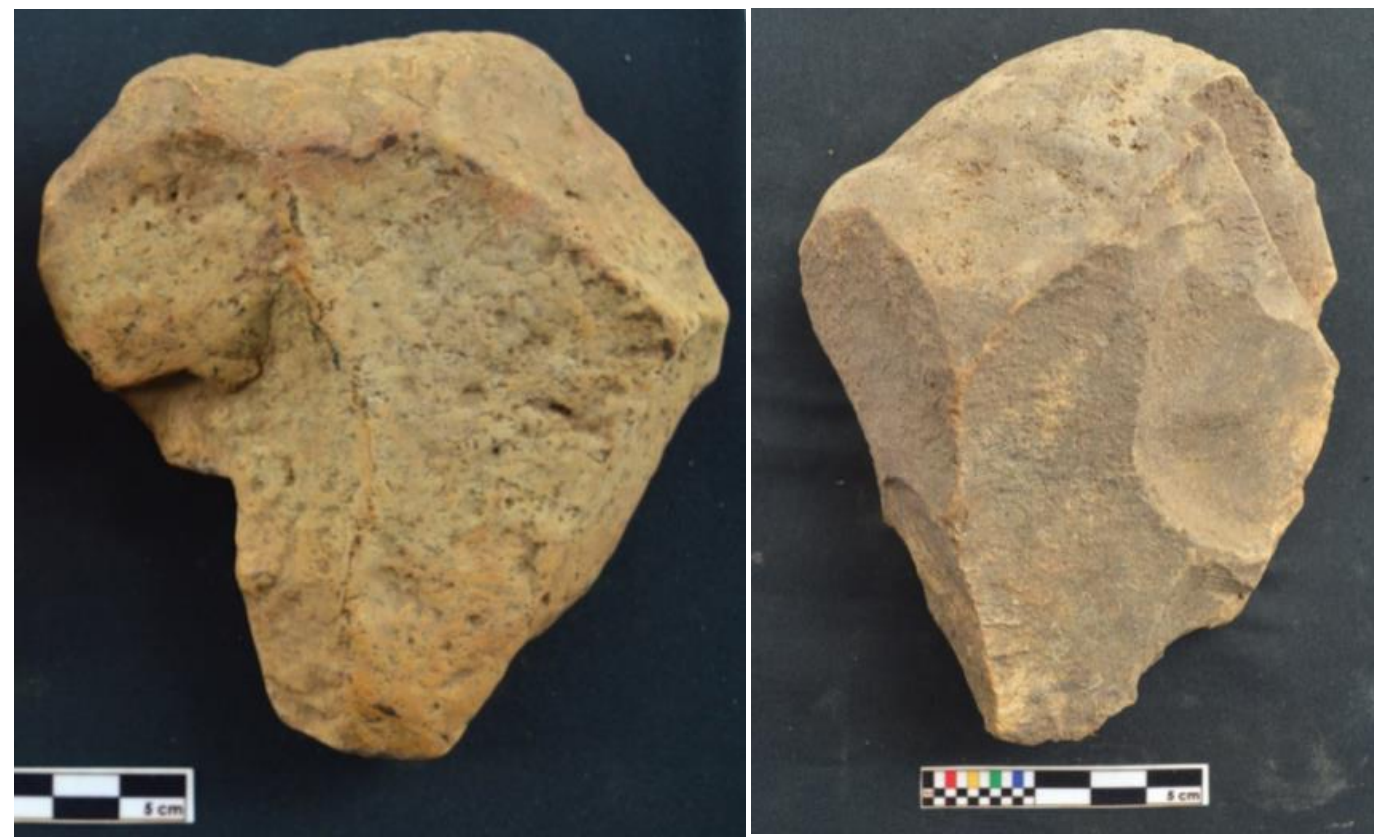

Gambar 12. Alat serpih (dari batu inti) yang memiliki patina yang tebal dan ukurannya lebih besar

(Sumber: Dokumentasi Balar Sulsel, Tahun 2017) 

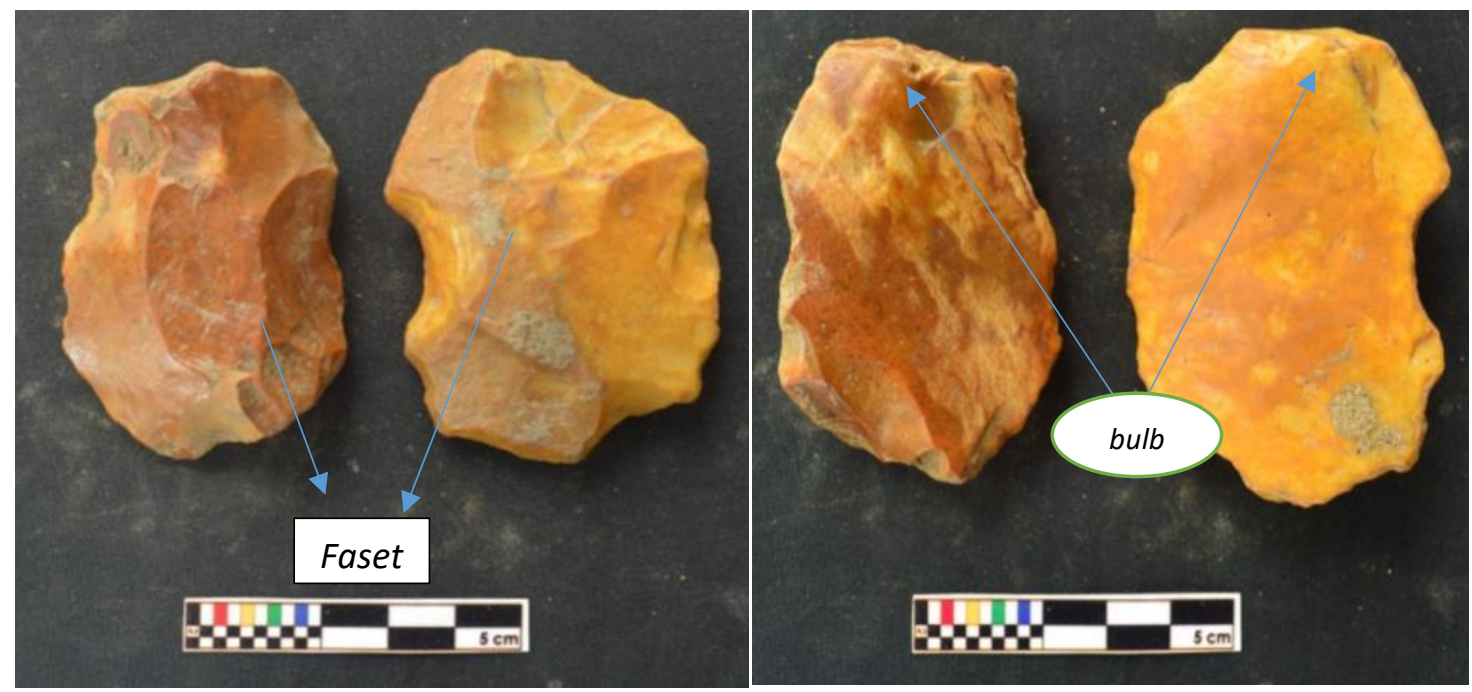

Gambar 13. Alat serpih (dari serpihan) berukuran sedang memiliki patina yang tebal serta faset maupun bulbus yang menumpul

(Sumber: Dokumentasi Balar Sulsel, Tahun 2017)

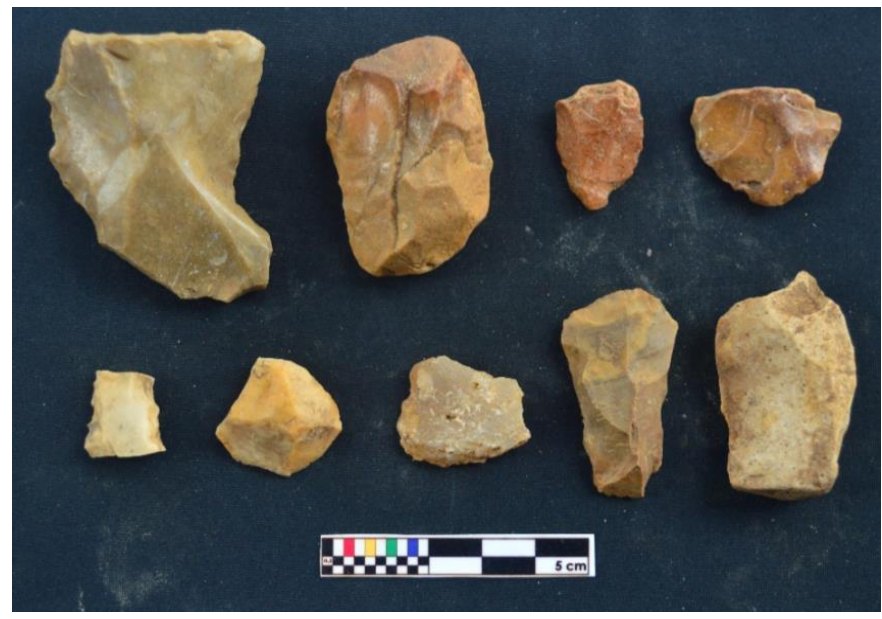

Gambar 14. Alat serpih ber-patina berukuran kecil dan alat serpih yang memiliki faset segar

(Sumber: Dokumentasi Balar Sulsel, Tahun 2017)

59 dan masing-masing dari situs Lita sebanyak 9, Situs Pising sebanyak 4, Situs Lompo sebanyak 4, Situs Bulu Mallaga 2, Situsa Palakka 8, Situs Daue 1, Situs Nyappareng 8, dan Situs Tanah Tappae 22. Sementara alat serpih dengan faset segar seluruhnya ditemukan sebanyak 36, masingmasing dari situs Palakka 5, situs Nyappareng 9, situs Mallinrung 5, situs Tanah Tappae 1, situs Daue 6, dan situs Bul u Mallaga 10.

Jika berdasarkan matriks, bahan dan teknik pembuatan tampaknya alat litik jenis serpih yang memiliki patina tebal yang ditemukan di wilayah Bone tersebut, memiliki persamaan dengan alat serpih yang tersebar di situs-situs paleolitik di wilayah Cabbenge, Soppeng. Kemungkinan masa pembuatan dan manusia pendukungnya berasal dari satu generasi yang sama pula. Alat serpih yang berukuran besar memiliki panjang antara $4 \mathrm{~cm}-9 \mathrm{~cm}$, lebar $3.2 \mathrm{~cm}-$ $8 \mathrm{~cm}$ dan tebal $9 \mathrm{~mm}-3 \mathrm{~cm}$.

\section{b. Kapak Genggam (Hand Axe)}

Alat ini disebut kapak genggam karena secara morfologi memiliki bentuk menyerupai kapak (tajaman yang meruncing), tetapi tidak bertangkai dan digunakan dengan cara digenggam. 

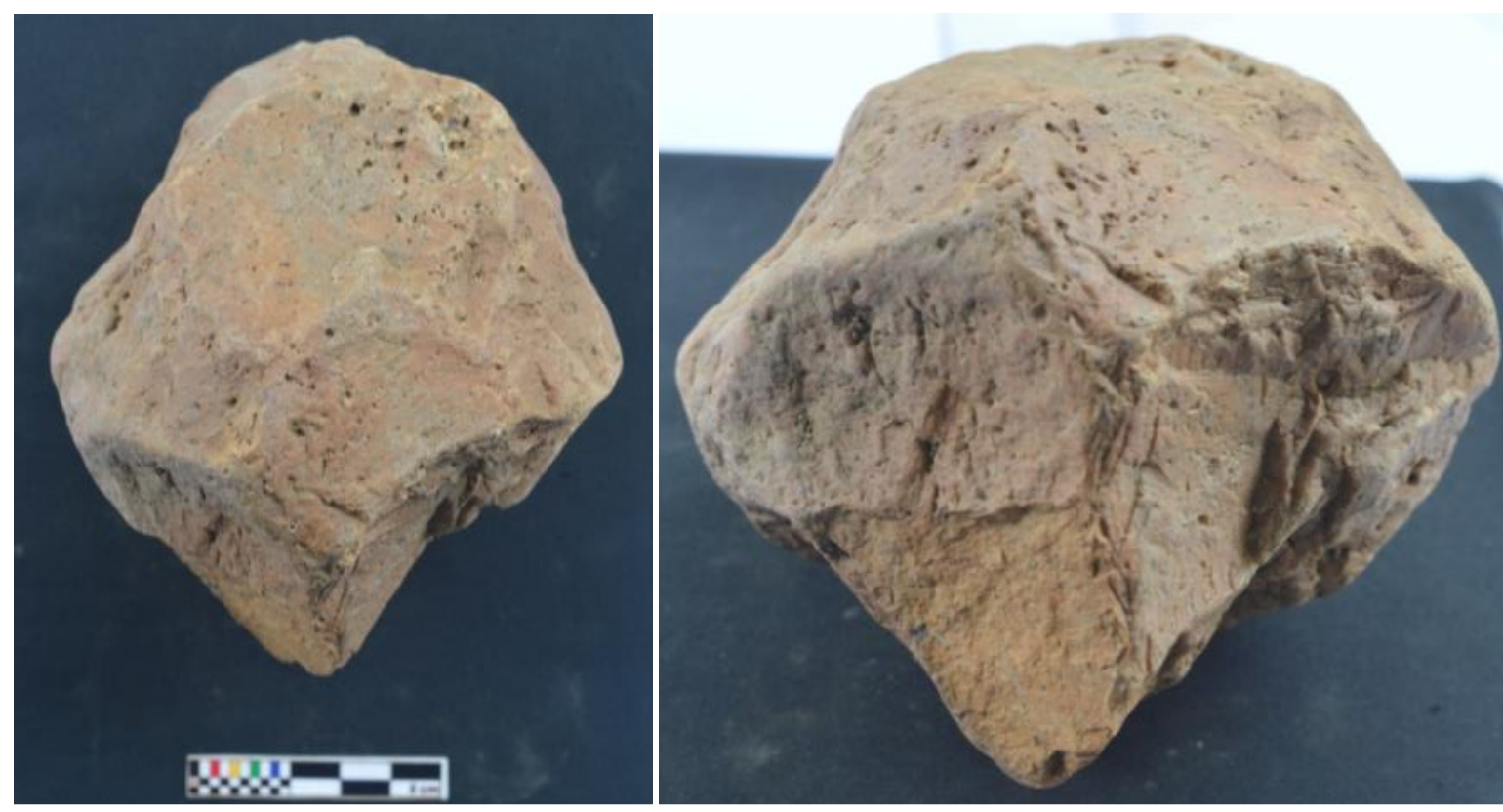

Gambar 15. Kapak Genggam dua sisi yang ditemukan di Bone

(Sumber: Dokumentasi Balar Sulsel, Tahun 2017)

Pembuatan kapak genggam dilakukan dengan cara memangkas salah satu sisi batu sampai tajam dan sisi lainnya dibiarkan apa adanya sebagai tempat menggenggam. Kapak genggam secara fungsional dipakai sebagai alat penggali umbi, memotong dan menguliti binatang.

Dalam survei di kawasan Bone bagian barat menunjukkan bahwa tidak semua situs ditemukan adanya kapak genggam. Selain, karena sebagian situs yang disurvei telah mengalami gangguan oleh adanya aktivitas penambangan pasir dan batu, sehingga alat litik (mungkin termasuk kapak genggam) terbawa ke tempat lain atau kemungkinan memang di situs tersebut tidk diproduksi kapak genggam. Terdapat 4 kapak genggam yang ditemukan di wilayah Bone bagian barat ini, rata-rata memiliki ukuran panjang antara $12-13 \mathrm{~cm}$ dan lebar 8$11 \mathrm{~cm}$ serta umumnya dibuat dari batuan silika, yaitu gamping kersikan. Situs yang mengandung temuan kapak genggam adalah situs Daue, Kecamatan Libureng dan Situs Lita, Kecamatan Lamuru.

Umumnya kapak genggam yang ditemukan di wilayah Kabupaten Bone bagian barat memiliki ukuran yang relatif besar dan umumnya memiliki faset serpihannya sudah sangat tersamar oleh adanya patina yang cukup tebal. Hal ini dimungkinkan oleh tingkat transformasi dari alat tersebut sejak tidak terpakai lagi di masa lalu hingga ditemukan saat ini. Sebaran kapak genggam di Sulawesi Selatan, antara lain ditemukan di situs-situs Lembah Walennae, Cabbenge, Kabupaten Soppeng; situs-situs di Singa, Kabupaten Bulukumba dan situs-situs gua prasejarah di Kabupaten Maros dan Pangkep.

Penemuan kapak genggam di luar Sulawesi, yaitu Jawa dan Sumatera. Di Jawa, khususnya di Pacitan dan Punung tergolong temuan yang banyak dan penting. Kapak genggam adalah unsur pokok budaya paleolitik di Luar Asia Tenggara dan Asia Timur dan merupakan himpunan temun litik yang menempati urutan ketiga dalam semua artefak litik dalam budaya Pacitan. Umumnya kapak-kapak genggam ini dipahat kasar secara memanjang, yaitu suatu teknik yang umum pada budaya kapak perimbas, tetapi ada juga beberapa buah yang diserpih dengan teliti dan dibentuk teratur (lonjong, bundar) dan alat-alat ini dapat digolongkan sebagai contoh yang 

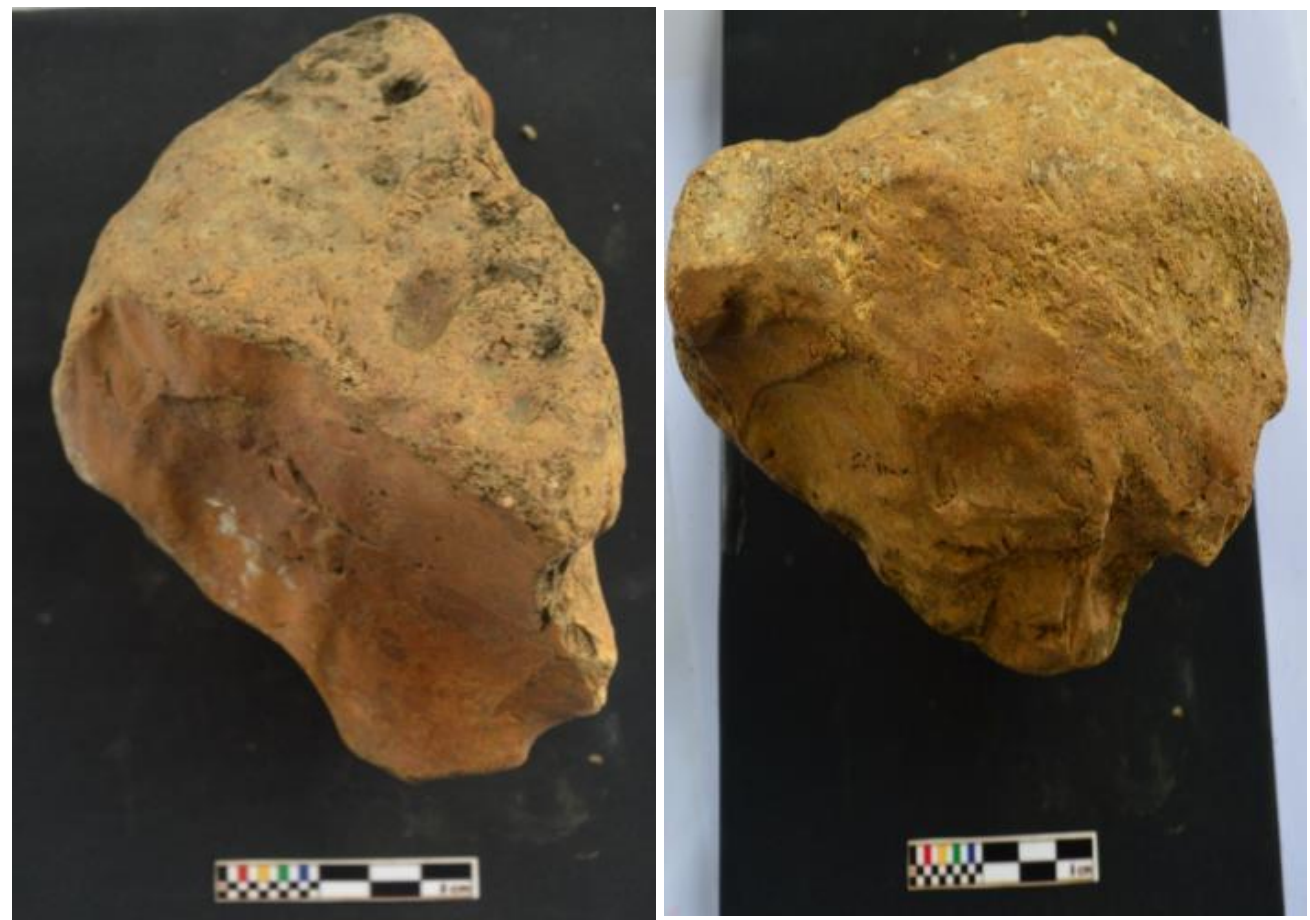

Gambar 16. Kapak perimbas dari dua sisi

(Sumber: Dokumentasi Balar Sulsel, Tahun 2017)

mirip dengan alat-alat tingkat Acheulean Awal, yaitu suatu tingkat budaya paleolitik di Eropa dan Afrika yang sudah mulai maju (Poesponegoro \& Notosusanto, 1984, p. 105).

\section{c. Kapak Perimbas (Chopper)}

Alat ini sering diterjemahkan oleh para arkeolog sebagai alat batu masif yang masih kasar dalam pembuatannya. Kapak perimbas dibuat dengan meruncingkan batu pada salah satu sisi permukaannya untuk memperoleh bagian tajaman. Bagian lain dari alat tersebut tidak dipertajam merupakan area pegangan yang cukup nyaman. Kapak perimbas benar-benar dirancang sesuai dengan ukuran telapak tangan penggunanya. Meskipun dari bentuk dan teknologinya sangat sederhana, namun alat batu ini telah sukses mendampingi manusia dalam segala kondisi selama ratusan ribu tahun. Dan yang menarik adalah bahwa alat ini hadir dihampir semua peradaban manusia.

Demikian halnya kapak perimbas yang ditemukan dalam survei di wilayah bagian barat Kabupaten Bone. Secara teknologi menunjukkan pengerjaan yang cukup sederhana, yaitu hanya pada satu sisi dipangkas secara melandai. Tajaman alat memperlihatkan retus akibat pemakaian secara intensif dan sebagian besar kulit batu (korteks) masih ada.

Alat batu jenis ini ditemukan sebanyak 15, masing-masing dari situs Lita 2, situs Lompo 1, situs Palakka 3, situs Daue 5, situs Mallinrung 1, dan situs Tanah Tappae 3. Sementara bahan yang dipakai umumnya dari batuan gamping kersikan disamping bahan lainnya (tufa kersikan). Adapun ukuran panjang alat ini, yaitu panjang antara $12 \mathrm{~cm}-17 \mathrm{~cm}$, lebar antara $10-12 \mathrm{~cm}$ dan tebal antara $8-9 \mathrm{~cm}$.

\section{d. Kapak Penetak}

Alat batu ini secara teknologi memperlihatkan pemangkasan pada bagian tepi dari permukaan atas dan bawah yang saling berhadapan. Akibat pemangkasan yang demikian telah diperoleh tajaman yang berliku. Kapak batu yang memiliki ciri demikan dalam survei di Bone barat telah 

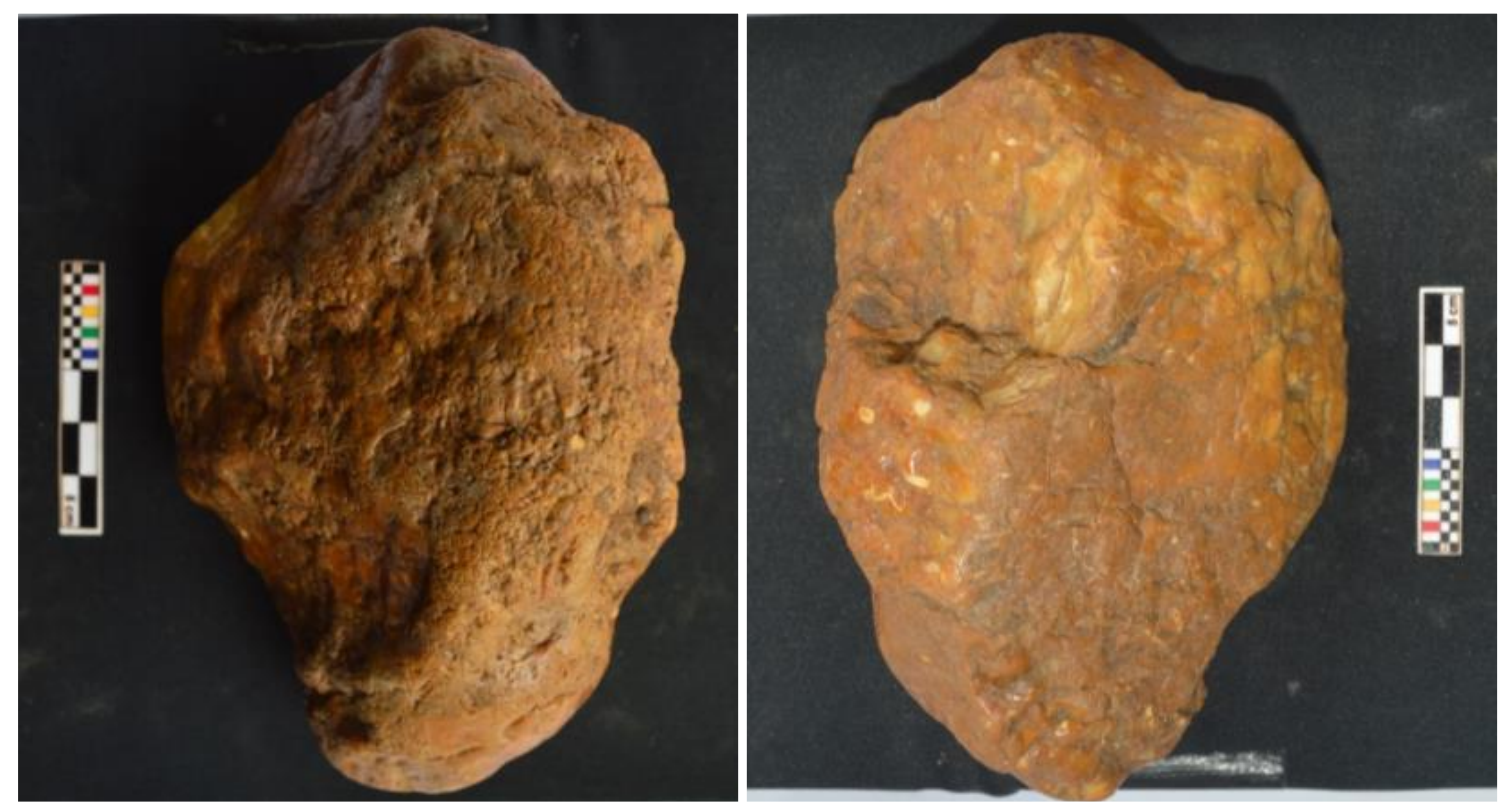

Gambar 17. Kapak penetak yang di temukan di Bone

(Sumber: Dokumentasi Balar Sulsel, Tahun 2017)

ditemukan sebanyak 17 yang masingmasing dari situs Lita 3, situs Lompo 1, situs Palakka 2, situs Daue 4, situs Nyappareng 4, dan situs Tanah Tappae 3.

Adapun ukuran kapak ini rata-rata memiliki panjang $7.5 \mathrm{~cm}-12 \mathrm{~cm}$, lebar ratarata antara $10 \mathrm{~cm}$ dan tebal rata-rata $4.5 \mathrm{~cm}$ - $5.5 \mathrm{~cm}$. Sementara bahan yang dipergunakan umumnya dari batuan kersikan, seperti gamping kersikan disamping batuan jasper, tufa kersikan dan lain sebagainya. Secara umum teknologi yang tampak pada kapak penetak yang ditemukan di wilayah Bone tersebut, memiliki persamaan dengan kapak penetak di daerah Soppeng.

Temuan survei berhasil mengumpulkan sejumlah jenis artefak alat litik yang secara teknologi memiliki ciri alat paleolitik juga dalam himpunan alat batu ditemukan banyak batu inti (bahan batuan) yang pada salah satu sisinya memperlihatkan bidang-bidang bekas pangkasan. Batu inti yang berhasil dikumpulkan memiliki ukuran bonggol yang bervariasi dari yang berukuran kecil hingga yang berukuran besar, yaitu panjang antara $4 \mathrm{~cm}$ hingga $12 \mathrm{~cm}$ (lihat foto 48).
Merujuk pada artefak yang ditemukan pada situs-situs yang ada di wilayah Bone barat, menunjukkan bahwa teknologi alat batu mulai dari jenis alat serpih, kapak perimbas, dan kapak penetak, ditemukan di hampir semua situs yang telah disurvei. Pengecualian pada temuan kapak genggam yang hanya ditemukan di situs Daue dan situs Lita. Meski temuan kapak genggam tidak banyak ditemukan di situssitus yang lain, namun teknologi alat batu di dua situs tersebut memiliki kesamaan dengan temuan serupa di situs-situs yang ada di wilayah Soppeng, khususnya di Lembah Walennae, serta di wilayah-wilayah depresi Walennae Purba yaitu di wilayah Bulukumba, Maros dan Pangkep.

Situs Lita dan Situs Daue juga memiliki keistimewaan, dimana pada dua situs tersebut dijumpai ragam teknologi alat batu, diantaranya alat serpih, kapak genggam, kapak perimbas, dan kapak penetak. Hal ini menunjukkan bahwa teknologi alat batu di situs-situs tersebut memiliki perkembangan yang lebih maju dibanding situs-situs lainnya. Kondisi lingkungan tentu saja berperan sangat penting dalam menunjang perkembangan 
teknologi alat batu tersebut khususnya aspek sumber bahan di sekitarnya.

\section{Perkembangan Budaya Paleolitik di Kabupaten Bone, Sulawesi Selatan}

Dari sudut tipologi dan teknologi alat batu yang ditemukan di wilayah Kabupaten Bone, seperti alat inti (kapak penetak, perimbas, dan Kapak genggam) dan alat sepih yang berpatina serta alat serpih yang memiliki faset yang masih segar memiliki persamaan dengan alat-alat litik di Lembah Walennae, Cabbenge, Kabupaten Soppeng, termasuk yang berasal dari pertanggalan \pm 200 ribu tahun yang lalu. Persamaan bentuk, bahan dan teknologi bisa jadi berasal dari masa yang sama maupun manusia pendukung yang sama pula. Namun bisa juga berasal dari masa dan manusia pendukung yang berbeda.

Jika berdasarkan aspek teknologi ataupun aspek patinasi maupun kesegaran faset yang berbeda-beda dari himpunan alat litik di berbagai situs yang di survei di wilayah Kabupaten Bone Barat, besar kemungkinan situs tersebut bukan kontenmporer, tetapi berasal dari pertanggalan yang berbeda-beda. Jadi bisa saja sebagian alat batu yang ditemukan memang dibuat oleh manusia purba (Homo Erectus) hingga menjelang akhir plestosen, namun sebagian alat batu yang dikumpulkan telah diproduksi kemudian oleh manusia moderen (Homo Sapiens).

Tidak adanya situs paleoantropologi di sekitar situs paleolitik yang di survei di wilayah Kabupaten Bone bagian barat merupakan fenomena yang menarik untuk dipertanyakan. Apakah situs-situs paleolitik di wilayah Bone barat mempunyai keterkaitan dengan kontekstual dan kontemporer dengan situs paleoantropologi yang ada di Kabupaten Soppeng (Kecce, Calio, Jampu, Marale, Tociappa, dan Talepu) dan situs Tanrung, Kecamatan Ajangngale, Kabupaten Bone.

Situs-situs tempat penemuan alatalat litik, baik yang berpatinasi maupun yang masih segar dulunya merupakan teras sungai purba yang sekarang ini menjadi lokasi pemukiman, persawahan dan perkebunan masyarakat setempat. Hal ini dimungkinkan, selain permukaan tanahnya miring dan berteras-teras juga banyak singkapan kerakal sungai. Selain itu, seluruh situs yang mengandung alat litik berada tidak jauh dari tepian aliran Sungai Walennae sekarang.

Pada beberapa bagian (spot) pada situs tertentu, terlihat adanya singkapan batuan pasir (sands stone). Batuan pasir merupakan batuan yang mengikat fosil-fosil vertebrata di wilayah Soppeng. Jika demikian, besar kemungkinan di wilayah Bone bagian barat ada lapisan kehidupan binatang purba yang hidup lebih tua dari manusia purba maupun yang bertahan hidup hingga semasa dengan kehadiran manusia di daerah tersebut. Sementara itu, ekskavasi yang dilakukan di situs-situs gua di wilayah Bontocani menunjukkan sebagian besar jenis fauna yang ditemukan berasal dari periode yang lebih muda yaitu fauna bertulang belakang. Sisa fauna yang ditemukan juga menunjukkan pemanfaatan sebagai alat pelubang dan atau alat penusuk dengan ciri penggunaan yang masih dapat diamati (Fakhri, 2018).

Letak geografis situs-situs gua beserta lingkungannya memperlihatkan karekter pokok hunian purba, yaitu dekat dengan sumber air (sungai) dan kehidupan di alam terbuka. Keberadaan situs-situs di sepanjang Sungai Walennae, di wilayah Bone Barat merupakan contoh kecenderungan manusia purba menghuni lingkungan sungai. Kondisi ini dapat dipahami mengingat keberadaan air memberikan keragaman manfaat. Selain untuk memenuhi kebutuhan pokok, ketersedian air dalam suatu lingkungan akan mengundang berbagai binatang untuk hidup di sekitarnya. Keberadaan air memberikan kesuburan bagi pertumbuhan berbagai tanaman. Air sungai dengan aktivitas erosi dan sedimentasi cenderung menampakkan berbagai jenis batuan yang bermanfaat untuk 
bahan peralatan. Dan keberadaan sungai juga penting sebagai orientasi mobilitas manusia dalam memenuhi kebutuhan hidupnya agar terhindar dari kesesatan (Zaim et al., 2012, p. 122).

Situs-situs yang mengandung alat litik yang berpatinasi (Paleolitik) yang berada di wilayah Bone barat, walaupun ditemukan pada areal terbuka, kemungkinan menjadi ruang jelajah manusia purba yang terkoneksi dengan gua-gua karst di Bontocani, Bone dan gua-gua kapur yang ada di daerah Maros-Pangkep. Dalam konteks geografis berbeda yaitu di pesisir selatan Sulawesi, temuan-temuan alat litik dengan bahan yang berbeda berupa batuan vulkanik ditemukan di beberapa situs di Bantaeng, yaitu situs Batu Ejayya, Panganreang Tudea, dan Pattenungan (Hakim \& Suryatman, 2013; Suryatman, 2017). Karena ketiga daerah tersebut berbatasan langsung dengan situs-situs yang telah di survei di wilayah tersebut. Pendapat ini masih memerlukan penelitian lanjutan, khusus mengatahui lapisan hunian situssitus gua yang ada di wilayah karst Bontocani, Bone dan daerah sekitarnya.

\section{PENUTUP}

Jika berdasarkan morfologi, matriks, bahan dan teknologi artefak litik yang ditemukan di daerah aliran sungai Walennae, Bone barat, memiliki persamaan dengan alat litik yang ditemukan di lembah Walennae, Cabbenge. Hal ini, kemungkinan dibuat oleh generasi manusia yang sama dalam periode yang sama pula. Alasan tersebut diperkuat oleh keletakan situs yang berada di tepi aliran Sungai Walennae. Kemungkinan areal sebaran alat-alat litik di wilayah Bone Barat, khususnya yang berada di tepian Sungai Walennae adalah ruang jelajah dari manusia pendukungnya yang bermukim di sekitar gua-gua kawasan Bontocani, Bone atau kemungkinan yang bermukim di gua-gua karst yang ada di sebelah baratnya (sekitar wilayah Maros dan Pangkep). Hal ini menujukkan konektivitas diantara tiga wilayah tersebut sebagai wilayah sebaran artefak litik di daerah aliran sungai Walennae.

Sebaran situs di Bone barat yang mengandung temuan litik terkoneksi dengan Sungai Walennae, memberi kejelasan bahwa manusia pendukungnya sangat mengerti akan potensi alam yang ada, yaitu sumber air dan lingkungan alam yang subur. Air dalam masa prasejarah adalah penunjang utama dari keberlangsungan hidup dari suatu kelompok manusia, sebab adanya sumber air juga memancing berkumpulnya binatang buruan dan tumbuhnya tanaman yang menjadi sumber makanan.

Temuan artefak litik yang berciri paleolitik dari situs-situs yang berada di kawasan Bone barat, merupakan informasi baru yang tentunya menambah lagi koleksi dan sebaran situs paleolitik di Sulawesi Selatan. Dan tidak menutup kemungkinan masih ada situs lain yang ditemukan, terutama di daerah yang berada di tepian Sungai Walennae mulai dari Bone (hulu) hingga yang mengalir melalui wilayah Kabupaten Soppeng dan bermuara di Kabupaten Wajo. Demikian juga terhadap daerah lain di Sulawesi Selatan yang termasuk dalam depresi Walanaae purba, seperti Kabupaten Sinjai, Bulukumba, Wajo, dan lainya perlu mendapat perhatian pada penelitian akan datang. 


\section{DAFTAR PUSTAKA}

Bellwood, P. (2007). Prehistory of the Indo-Malaysian Archipelago. Sydney: ANU E Press.

Bergh, G. D. Van Den, Li, B., Brumm, A., Grun, R., Yurnaldi, D., Moore, M. W., ... Morwood, M. J. (2015). Earliest Hominid Occupation of Sulawesi. Nature, 000, 1-4.

Duli, A., \& Nur, M. (2016). Prasejarah Sulawesi. Makassar: FIB Press.

Fakhri. (2017). Indentifikasi rangka manusia Situs Gua Balang Metti, Kabupaten Bone, Sulawesi Selatan. Walennae, 15(2), 89-100.

Fakhri. (2018). Arkeofauna Kawasan Karst Bontocani Kabupaten Bone, Sulawesi Selatan. Walennae, 16(1), 21-38.

Hakim, B. (1990). Alat batu Situs Mallinrung, di Sisi Timur Sungai Walennae, Libureng, Bone. Universitas Hasanuddin.

Hakim, B. (2017). Interpretasi Awal Temuan Gigi Manusia di Situs Bala Metti, Bone dan Situs Leang Jarie, Maros, Sulawesi Selatan. Walennae, 15(1), 19-30.

Hakim, B., \& Suryatman. (2013). Stone Tools technology and occupation phases at Batu Ejayya, South Sulawesi. Review of Indonesian and Malaysian Affairs, 47, 47-62.

Heekeren, V. H. (1972). The Stone Age of Indonesia. Martinus Nijhoff.

Poesponegoro, M. D., \& Notosusanto, N. (1984). Sejarah Nasional Indonesia 1. Balai Pustaka.

Pope, G. (1984). Antropologi Biologi. Jakarta: Penerbit CV. Rajawali.

Suryatman. (2017). Artefak litik di Kawasan Prasejarah Batu Ejayya: Teknologi Peralatan Toalian di pesisir selatan Sulawesi Selatan. Walennae, 15(1), 1-18.

Zaim, Y., Tanudirjo, D., Widianto, H., \& Prasetyo, B. (2012). Manusia dan Budaya setelah zaman es terakhir. In Indonesia dalam arus Sejarah. PT. Ichtiar baru Van Hoeve dan Kemendikbud. 
Lampiran 1. Tabel nama situs dan jenis temuan di wilayah Bone barat

\begin{tabular}{|c|c|c|c|}
\hline No. & $\begin{array}{l}\text { Jenis } \\
\text { Temuan }\end{array}$ & Nama Situs & Keterangan \\
\hline $\mathbf{1}$ & $\begin{array}{l}\text { Alat Serpih } \\
\text { (Flake } \\
\text { Tools) }\end{array}$ & $\begin{array}{l}\text { - Situs Lita } \\
\text { - Situs Pising } \\
\text { - Situs Lompo } \\
\text { - Situs Bulu } \\
\text { Mallaga } \\
\text { - Situs Daue } \\
\text { - Situs Nyappareng } \\
\text { - Situs Tanah } \\
\text { Tappae }\end{array}$ & - \\
\hline 2. & $\begin{array}{l}\text { Alat Serpih } \\
\text { dengan faset } \\
\text { segar }\end{array}$ & $\begin{array}{l}\text { - Situs Palakka } \\
\text { - Situs Nyappareng } \\
\text { - Situs Mallinrung } \\
\text { - Situs Tanah } \\
\text { Tappae } \\
\text { - Situs Daue } \\
\text { - Situs Bulu } \\
\text { Mallaga }\end{array}$ & - \\
\hline 3 & $\begin{array}{l}\text { Kapak } \\
\text { Genggam } \\
(\text { Hand Axe) }\end{array}$ & $\begin{array}{l}\text { - Situs Lita } \\
\text { - Situs Daue }\end{array}$ & $\begin{array}{l}\text { Jenis temuan memiliki } \\
\text { kesamaan dengan temuan } \\
\text { di situs-situs Lembah } \\
\text { Walennae Soppeng, } \\
\text { Bulukumba, Maros dan } \\
\text { Pangkep }\end{array}$ \\
\hline 4 & $\begin{array}{l}\text { Kapak } \\
\text { Perimbas } \\
\text { (Chopper) }\end{array}$ & $\begin{array}{l}\text { - Situs Lita } \\
\text { - Situs Lompo } \\
\text { - Situs Palakka } \\
\text { - Situs Daue } \\
\text { - Situs Mallinrung } \\
\text { - Situs Tanah } \\
\quad \text { Tappae }\end{array}$ & - \\
\hline 5 & $\begin{array}{l}\text { Kapak } \\
\text { Penetak } \\
\text { (Chopping } \\
\text { Tools) }\end{array}$ & $\begin{array}{l}\text { - Situs Lita } \\
\text { - Situs Lompo } \\
\text { - Situs Palakka } \\
\text { - Situs Daue } \\
\text { - Situs Nyappareng } \\
\text { - Situs Tanah } \\
\text { Tappae }\end{array}$ & $\begin{array}{l}\text { Jenis temuan memiliki } \\
\text { kesamaan teknologi } \\
\text { dengan temuan serupa di } \\
\text { situs-situs paleolitik di } \\
\text { wilayah Soppeng }\end{array}$ \\
\hline
\end{tabular}

Sumber: Balar Sulsel, Tahun 2017 